\title{
Heavy metals and organic micropollutants in floodplains of the river Waal, a distributary of the river Rhine, 1958-1981
}

\author{
J. JAPENGA, K. H. ZSCHUPPE, A. J. DE GROOT \& W. SALOMONS \\ Institute for Soil Fertility Research / Delft Hydraulics (Haren Branch), P.O. Box 30003, \\ NL. 9750 RA Haren, Netherlands
}

Received 18 January 1990; accepted 10 April 1990

\begin{abstract}
During periods of high water discharge, dyke-protected floodplains of the river Rhine in the Netherlands become inundated and suspended matter from the river settles out. In the last 30 years, floodplain top layers have been sampled several times just after deposition; samples were dried and stored in a specimen bank. We used these samples to assess the development of sediment contamination with heavy metals and organic micropollutants during the past decades. Heavy metals investigated include zinc, copper, chromium, lead, cadmium, nickel, mercury and arsenic. Different groups of chemically persistent organic micropollutants were studied: polycyclic aromatic hydrocarbons (PAH); polychlorobiphenyls (PCB), hexachlorobenzene (HCB), DDT and DDT-metabolites. In general, the levels of most contaminants decreased substantially between 1958 and 1981 . The variation among the different floodplain locations is due to differences in hydrodynamic characteristics of the location. A comparison was made between the concentrations found and the levels considered acceptable if the floodplain area is used for cattle grazing; a comparison was made also with estimated natural background levels and with reference values defined by the Dutch government.
\end{abstract}

Keywords: cadmium, floodplains, heavy metals, mercury, organic micropollutants, PCB's, Rhine

\section{Introduction}

During spring, water discharges in the river Rhine increase, causing inundation of the floodplains along the river and along its branches in the Netherlands. During the inundation periods, suspended solids settle on the floodplain, leaving behind a thin layer of sediment (about 1-5 mm).

Figure 1 shows a cross section of a typical floodplain/river system in the lower Rhine area. Generally, a low summer dyke and a high winter dyke are part of the system (right-hand side of Fig. 1). At some locations, however, no summer dyke is present (left-hand side of Fig. 1). The summer dyke protects the area between the two dykes during periods of normal and moderately increased water discharges, making cattle grazing and brick production possible during the summer period. 


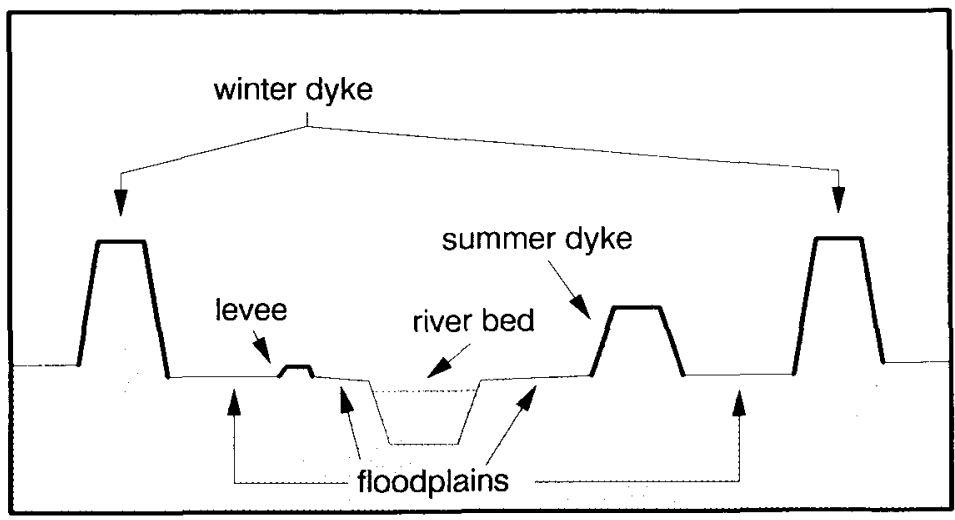

Fig. 1. Cross section of a typical dyke-protected floodplain system in the Dutch lowland.

With increasing water discharge the area within the summer dykes becomes inundated first and finally the area between the summer and winter dykes; this last event takes place only at high water discharge, on average once every two years. The entire land area between the winter dykes is generally considered as floodplain. The total floodplain area along the river Rhine and its distributaries in the Netherlands is about 40000 ha.

Freshly deposited sediment from the floodplain areas has been sampled for different purposes since 1958. Sampling took place through the careful removal of freshly deposited material immediately after the floodplain area fell dry; the samples were taken by the same technician from 1958 to 1981, which reduced variation in sampling technique to a minimum. The fact that the samples were stored in a specimen bank gave an excellent opportunity to investigate the changes in floodplain contamination during the last decades.

Contaminant levels in the floodplain sediments are important:

- as an indication of river pollution,

- in relation to plant uptake (generally grass), and

- in relation to animal uptake through the consumption of polluted grass but also through direct ingestion of soil.

\section{Materials and methods}

\section{Sampling scheme}

Figure 2 shows all sampling locations involved in this study: sampling areas situated between summer and winter dykes and sampling areas not separated from the river bed by a summer dyke are indicated.

Heavy-metal concentrations were determined in samples from 13 different locations along the river Waal, the largest distributary of the river Rhine. Heavy metals were also determined in the upper $5 \mathrm{~cm}$ layer of a number of floodplain areas in 


\begin{tabular}{|ll|}
\hline \multicolumn{2}{|l|}{ Location: } \\
1 & Dutch/German border \\
2 & Spijk \\
3 & Pannerdense Kop \\
4 & Doornik/Bemmel \\
5 & Lent \\
6 & Oosterhout \\
7 & Winssen \\
8 & Deest \\
9 & IJzendoorn \\
10 & Tiel \\
11 & Varik \\
12 & Hellouw \\
13 & Daiem \\
\hline
\end{tabular}

\section{THE NETHERLANDS}

Rhine-Meuse area indicated
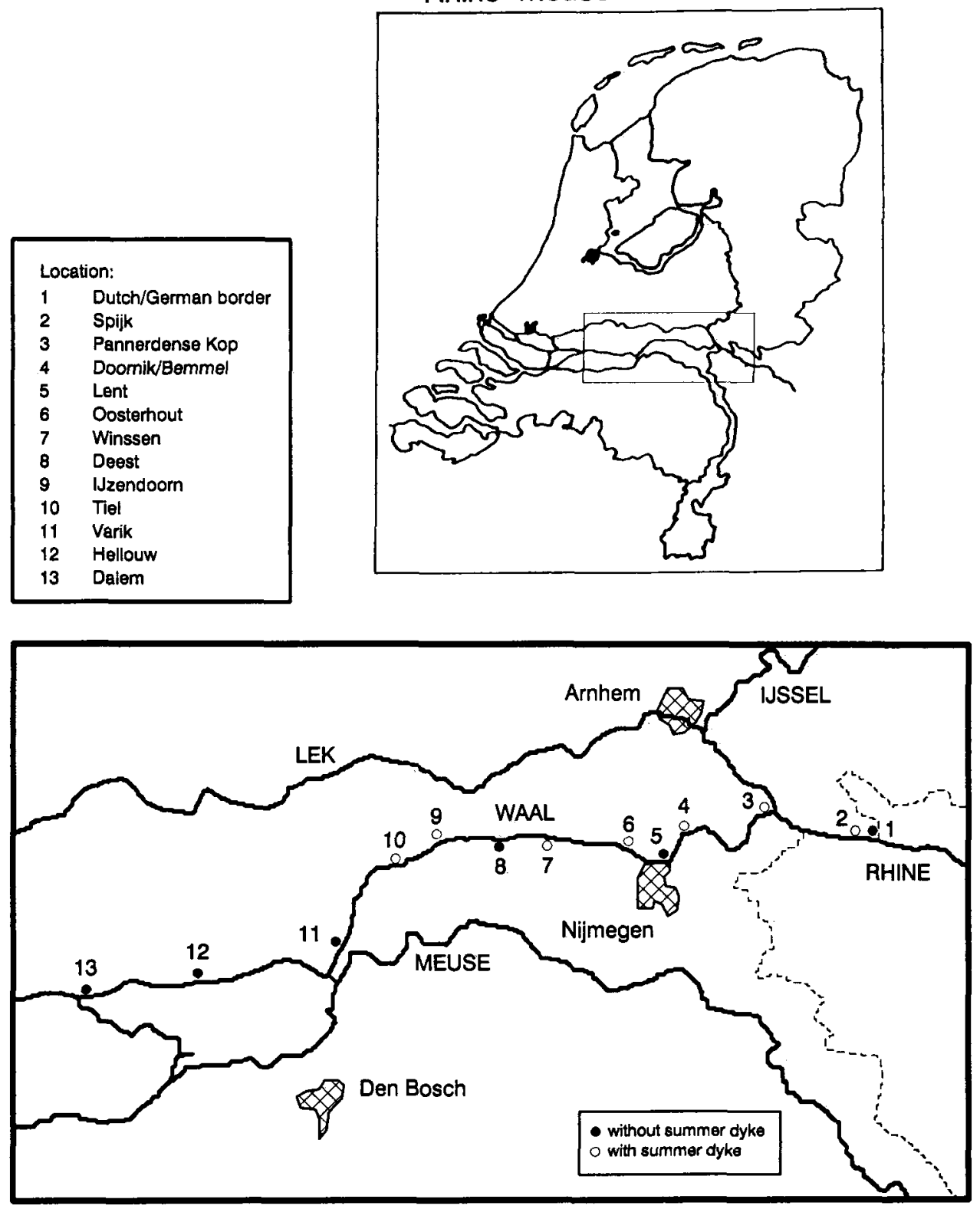

Fig. 2. Map of the Rhine river system in the Dutch lowland, indicating floodplain areas and sediment sampling sites. 
Table 1. Sampling scheme for heavy metal and organic micropollutant determinations in floodplains; number of samples in every sampling year.

\begin{tabular}{lllllllllllll} 
Location & \\
\hline 1 & 2 & 3 & 4 & 5 & 6 & 7 & 8 & 9 & 10 & 11 & 12 & 13
\end{tabular}

Heavy metals

1958 (surface sample)

1970 (surface sample)

1972 (surface sample)

1981 (surface sample)

1969 (core sample)

$\begin{array}{rrrrrrrrrrrrr}2 & - & 5 & 2 & 2 & - & - & - & - & - & - & - & - \\ 10 & 19 & - & 9 & 9 & 10 & 10 & 10 & 10 & 5 & 10 & 10 & 10 \\ 6 & 4 & 10 & - & - & - & - & - & - & - & 10 & - & - \\ 8 & 8 & 10 & 10 & 6 & 10 & 8 & 8 & 8 & 8 & 10 & 10 & 10 \\ 5 & 2 & - & 5 & - & - & - & - & 10 & 10 & 10 & 10 & 10\end{array}$

Organic micropollutants

1958 (surface sample)

1970 (surface sample)

1972 (surface sample)

1981 (surface sample)

1969 (core sample)

\begin{tabular}{lllllllllllll}
6 & - & 6 & 2 & 2 & - & - & - & - & - & - & - & - \\
4 & 4 & - & 4 & 4 & - & - & - & - & 4 & 4 & - & - \\
4 & 4 & 4 & - & - & - & - & - & - & - & 4 & - & - \\
4 & 4 & 4 & 4 & 4 & - & - & - & - & 4 & 4 & - & - \\
- & - & - & - & - & - & - & - & - & - & - & - & - \\
\hline
\end{tabular}

1969; these samples, however, did not consist of freshly settled sediment, but of a series of consecutive sediment deposits.

Organic micropollutants were determined in a smaller number of samples from only 7 locations (all included in the heavy metal analysis scheme).

Sampling took place in $1958,1970,1972$ and 1981. It was not possible to sample all floodplain locations in every sampling year.

A survey of the samples analysed is given in Table 1.

\section{Analytical procedures}

To determine the organic matter content the sample was heated with a known amount of potassium dichromate in dilute sulphuric acid. The amount of dichromate not consumed in the oxidation process was determined through titration with ferrous ion. From the amount of consumed dichromate the organic matter content was estimated.

The percentages particles $<2 \mu \mathrm{m}$ and $<16 \mu \mathrm{m}$ in carbonate-free mineral matter were determined by a sedimentation method based on Stokes' law (Kilmer \& Alexander, 1949).

For the determination of heavy metal concentrations the dry sediments were treated with mixtures of oxidizing strong acids; depending on the element to be determined a specific acid mixture was chosen:

- $\mathrm{Zn}, \mathrm{Cu}, \mathrm{Cr}, \mathrm{Ni}$ : hot mixture of sulphuric, nitric and perchloric acids,

- As: hot mixture of sulphuric, nitric and perchloric acids followed by treatment with hydrochloric acid/potassium iodide/ascorbic acid, 
- Hg: cold mixture of sulphuric acid, nitric acid and potassium persulphate,

- $\mathrm{Pb}, \mathrm{Cd}$ : hot nitric acid and final transfer to hydrochloric acid.

Analyses were carried out using flame-AAS techniques, except for As and $\mathrm{Hg}$ (Vierveijzer et al., 1979).

As and $\mathrm{Hg}$ were determined with cold AAS techniques after reduction of all chemical forms of arsenic and mercury to arsenic hydride and metallic mercury, respectively.

The analytical method for the determination of organic micropollutants has been described earlier (Japenga et al., 1987). Results are generally given as the sum of individual components:

- PAH: the sum of 6 individual PAH's (Borneff \& Kunte, 1969),

- PCB: the sum of 6 congeners (numbers 28, 52, 101, 138, 153 and 180) together accounting for about $30-40 \%$ of total PCB,

- DDT: the sum of $o, p^{\prime}$ - and $p, p^{\prime}$-DDT and their DDD- and DDE-metabolites.

\section{Treatment of data}

Experimentally found pollutant concentrations in sediments have to be compared with reference values in order to classify the degree of pollution and to decide on possible pollution control measures. Reference values for individual pollutants were established by the Dutch authorities (Anonymous, 1987, 1988). They represent upper limits for heavy metal concentrations in soils at which all soil functions still proceed normally. Reference values were derived from the following formulas:

$$
\begin{aligned}
& C^{\prime}(\mathrm{Zn})=C(\mathrm{Zn}) \times 140 /[50+1.5 \times(2 L+H)] \\
& C^{\prime}(\mathrm{Cu})=C(\mathrm{Cu}) \times 36 /[15+0.6 \times(L+H)] \\
& C^{\prime}(\mathrm{Cr})=C(\mathrm{Cr}) \times 100 /[50+2 \times L] \\
& C^{\prime}(\mathrm{Pb})=C(\mathrm{~Pb}) \times 85 /[50+(L+H)] \\
& C^{\prime}(\mathrm{Cd})=C(\mathrm{Cd}) \times 0.8 /[0.4+0.007(L+3 H)] \\
& C^{\prime}(\mathrm{Ni})=C(\mathrm{Ni}) \times 35 /[10+L] \\
& C^{\prime}(\mathrm{Hg})=C(\mathrm{Hg}) \times 0.3 /[0.2+0.0017 \times(2 L+H)] \\
& C^{\prime}(\mathrm{As})=C(\mathrm{As}) \times 29 /[15+0.4 \times(L+H)]
\end{aligned}
$$

where:

$C^{\prime}=$ normalized heavy metal concentration

$C=$ measured heavy metal concentration $\left(\mathrm{mg} \mathrm{kg}^{-1}\right.$ dry matter)

$L=$ clay content $($ particles $<2 \mu \mathrm{m})(\%)$

$H=$ measured organic matter content $(\%)$

To make comparisons possible, experimental data and reference values were adjusted to fit standard soil composition ( $25 \%$ clay and $10 \%$ organic matter).

By another normalization method, measured concentrations are extrapolated to material containing $50 \%$ particles $<16 \mu \mathrm{m}$ in the carbonate-free mineral matter. This method has been commonly used for aquatic sediments (de Groot et al., 1982). In the following paragraphs it is used only if comparison is intended with literature 
data sets based on this normalization method.

Organic micropollutants are considered to be bound mainly to the organic matter fraction. Experimentally found concentrations are normalized to soil containing $10 \%$ organic matter:

$$
C^{\prime}=C \times 10 / H
$$

where:

$C^{\prime}=$ normalized organic micropollutant concentration

$C=$ measured concentration of organic micropollutant $(\mathrm{PAH}, \mathrm{PCB}, \mathrm{DDT}$, $\mathrm{HCB})$

$H=$ measured organic matter content $(\%)$

\section{Results and discussion}

\section{Sample characterization}

The samples varied widely in carbonate, organic matter and clay contents. Average values did not vary significantly with respect to the sampling site, but some variation between years can be observed. Average percentages (with minimum and maximum values in parentheses) are summarized in Table 2 .

\section{Drying procedure}

To determine whether the drying procedure used in the past caused any loss of components, a preliminary experiment was carried out. A wet sediment sample with only $1.4 \%$ organic matter (corresponding to a low binding capacity for organic micropollutants) was analysed for PAH, PCB, DDT and HCB. The same sample was dried at $50-70{ }^{\circ} \mathrm{C}$ for 5 days and then the analyses were repeated. At temperatures below $70{ }^{\circ} \mathrm{C}$ only negligible losses occurred.

Table 2. Average contents (\%) of organic matter, particles $<16 \mu \mathrm{m}$, and calcium carbonate in river Waal floodplain sediments (minimum and maximum values in parentheses).

\begin{tabular}{lllll}
\hline & \multicolumn{2}{l}{ Sampling year } & & \\
\cline { 2 - 5 } & 1958 & 1970 & 1972 & 1981 \\
Organic matter & 14.5 & 11.1 & 12.3 & 10.4 \\
& $(11.7-18.9)$ & $(3.6-15.4)$ & $(8.4-14.5)$ & $(1.2-18.4)$ \\
Particles $<16 \mu \mathrm{m}$ & 58.3 & 64.4 & & \\
& $(38.2-72.7)$ & $(17.4-87.2)$ & $(28.2-88.1)$ & $(6.9-86.2)$ \\
Calcium carbonate & 13.2 & 10.2 & & 8.7 \\
& $(12.0-14.1)$ & $(5.5-12.4)$ & $(11.3-16.5)$ & $(1.7-10.8)$ \\
\hline
\end{tabular}


As all floodplain samples were dried just after collection at $40{ }^{\circ} \mathrm{C}$ for one night and as their organic matter contents exceeded $1.4 \%$ it can be concluded that the drying procedure did not cause any detectable loss of compounds through volatilization. Biodegradation in the air-dried sediment samples was considered negligible.

\section{Pollution levels in the period 1958-1981}

Heavy metal contents are given in Table 3 as the arithmetic mean of the concentration values corrected for clay/organic matter for all analysed floodplain sediment samples per sampling year. The 1969 core samples are included in the table; they agree quite well with the 1958-1970 fresh sediment samples. Figure 3 shows the timecourse of heavy metal contamination of the river Waal floodplains; 1958 is the reference level taken as unity. To improve visualization, all samples taken in 1970 and 1972 were combined. Between 1958 and 1970/72, cadmium levels nearly doubled; copper and mercury levels increased slightly. In the same period the concentration levels of the other heavy metals decreased slightly (zinc, chromium, lead) or dramatically (arsenic); there was little change in nickel levels. After 1970/72 the concentrations of all heavy metals except nickel decreased sharply. Nickel levels remained constant during the whole period studied, which may be attributed to a mainly natural origin of nickel (this will be shown later).

Contents of organic micropollutants are given in Table 4 as the arithmetic mean of the concentration values corrected for organic matter content for all analysed floodplain sediment samples per sampling year.

Figure 4 shows the time-course of pollution levels based on the data in Table 4 . In order to improve visualization, all 40 samples taken in 1970 and 1972 were combined. The values for 1958 were taken as the reference point $(=1)$ for the concentration changes observed.

The concentrations of $\mathrm{PAH}$ and DDT tended to decrease, especially after 1970/72. PCB and HCB increased substantially between 1958 and 1970/72, then decreased.

\section{Variations between floodplain locations}

Variation in heavy metal and organic micropollutant concentrations in the river Waal floodplains is much smaller when samples from one floodplain location collected in the same year are considered. It is clear that statistically significant differences exist between the locations. To find certain trends, heavy metal concentrations in relation to location characteristics were studied for two sampling years: 1970 and 1981. The reason for choosing these particular sampling years is the large number of locations sampled in these years. All locations were included except location 3 which was not sampled in 1970 . It must be stressed, however, that the results given below for heavy metal levels in 1970 and 1981 are representative of all other data.

To analyse differences in concentration levels between the sampling locations the following procedure was used: average adjusted concentrations of six heavy metals $(\mathrm{Zn}, \mathrm{Cu}, \mathrm{Cr}, \mathrm{Pb}, \mathrm{Cd}, \mathrm{Hg}$ ) were calculated for every location in 1970 and $1981 . \mathrm{Ni}$ 
Table 3. Average heavy metal concentrations, corrected for clay content and organic matter content, in river Waal sediments $\left(\mathrm{mg} \mathrm{kg}^{-1}\right)$. Coefficients of variation $(\%)$ are given in parentheses.

\begin{tabular}{lllllllllll}
\hline $\begin{array}{l}\text { Sampling } \\
\text { year }\end{array}$ & $\begin{array}{l}\text { Number of } \\
\text { samples }\end{array}$ & \multicolumn{2}{l}{ Element } \\
\cline { 3 - 11 } & & $\mathrm{Zn}$ & $\mathrm{Cu}$ & $\mathrm{Cr}$ & $\mathrm{Pb}$ & $\mathrm{Cd}$ & $\mathrm{Ni}$ & $\mathrm{Hg}$ & $\mathrm{As}$ \\
1958 & 11 & 1151 & 146 & 428 & 303 & 6.4 & 55 & 5.2 & 87 \\
& & $(8)$ & $(7)$ & $(40)$ & $(13)$ & $(13)$ & $(10)$ & $(12)$ & $(15)$ \\
1970 & 122 & 870 & 157 & 373 & 259 & 11.8 & 54 & 6.3 & 51 \\
& & $(17)$ & $(24)$ & $(31)$ & $(19)$ & $(27)$ & $(14)$ & $(33)$ & $(21)$ \\
1972 & 30 & 1147 & 185 & 404 & 336 & 14.9 & 54 & 6.5 & 35 \\
& & $(9)$ & $(5)$ & $(22)$ & $(10)$ & $(6)$ & $(9)$ & $(16)$ & $(13)$ \\
1981 & 114 & 656 & 104 & 214 & 173 & 7.5 & 53 & 1.2 & 24 \\
& & $(17)$ & $(18)$ & $(29)$ & $(19)$ & $(26)$ & $(17)$ & $(31)$ & $(18)$ \\
1969 & 62 & 1009 & 184 & 404 & 277 & 8.9 & 54 & 7.1 & 58 \\
(core samples) & & $(18)$ & $(23)$ & $(27)$ & $(16)$ & $(32)$ & $(17)$ & $(26)$ & $(20)$ \\
\hline
\end{tabular}

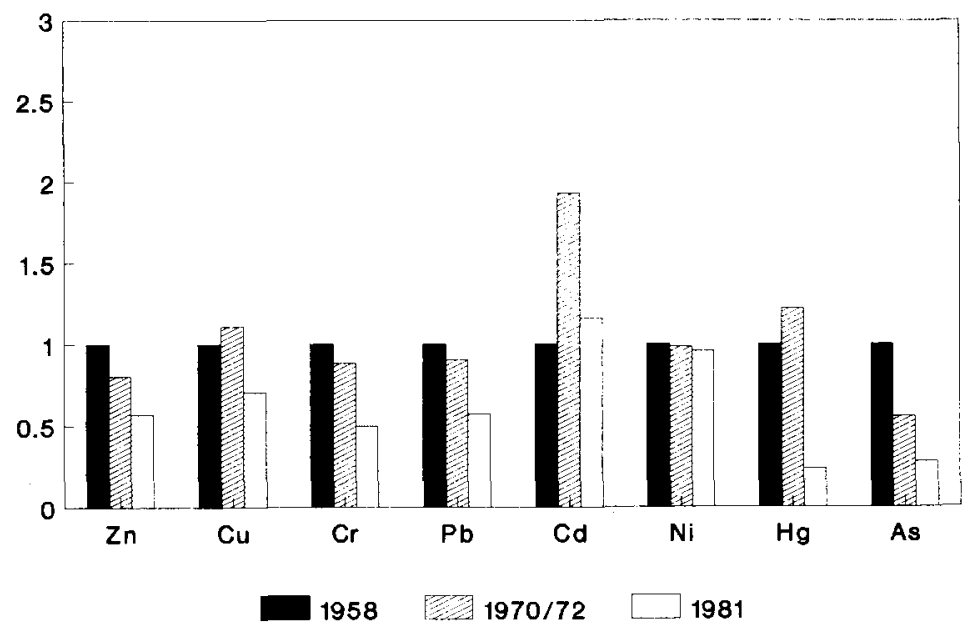

Fig. 3. Heavy metal pollution of freshly deposited sediments from the river Waal floodplains in different years $(1958=1)$.

and As were not included because their concentrations were not raised due to pollution; this will be shown later. The average concentration level of each element at each location was expressed in relation to the average value of the total sample set of that element in the sampling year considered (compare Table 3). In this way the relative deviations from the annual mean were obtained for every location and for every element in the same sampling year. 
Table 4. Average organic micropollutant concentrations, corrected for organic matter content, in river Waal sediments $\left(\mathrm{mg} \mathrm{kg}^{-1}\right)$. Coefficients of variation $(\%)$ are given in parentheses.

\begin{tabular}{llllll}
\hline Sampling year & $\begin{array}{l}\text { Number of } \\
\text { samples }\end{array}$ & \multicolumn{2}{l}{ Organic micropollutant } & \\
\cline { 3 - 6 } & & PAH & PCB & HCB & DDT \\
1958 & 16 & 16.8 & 0.49 & 0.14 & 0.28 \\
& & $(18)$ & $(39)$ & $(25)$ & $(21)$ \\
1970 & 24 & 12.0 & 0.96 & 0.38 & 0.29 \\
& & $(38)$ & $(47)$ & $(46)$ & $(30)$ \\
1972 & 16 & 13.3 & 0.99 & 0.36 & 0.25 \\
& & $(20)$ & $(29)$ & $(38)$ & $(26)$ \\
1981 & 28 & 7.2 & 0.40 & 0.28 & 0.15 \\
& & $(39)$ & $(45)$ & $(62)$ & $(40)$ \\
\hline
\end{tabular}

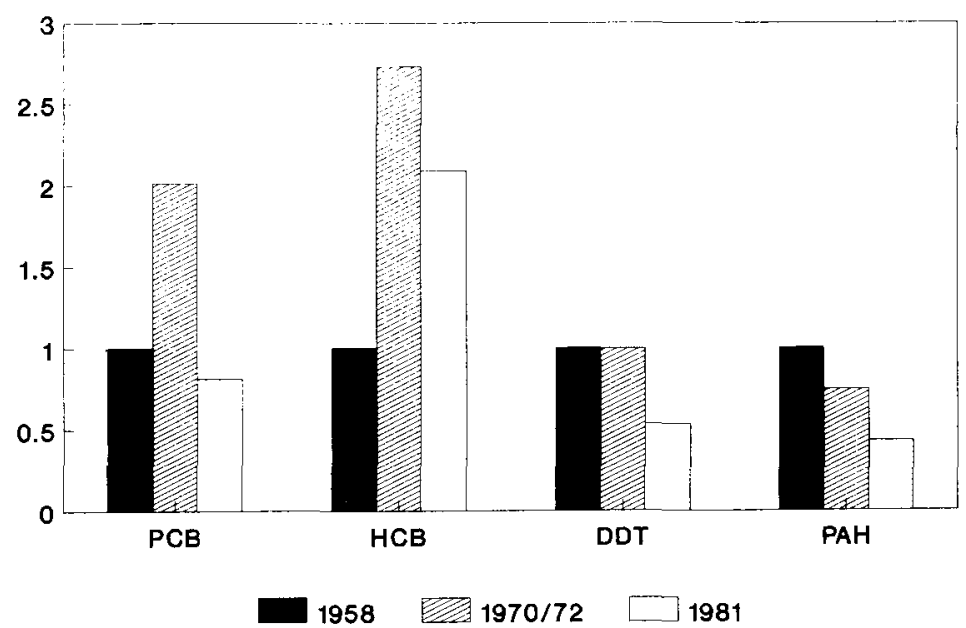

Fig. 4. Organic micropollutant pollution of freshly deposited sediments from the river Waal floodplains in different years $(1958=1)$.

Figure 5 gives the variation in heavy metal contamination between locations in 1970 and 1981 (normalized to standard soil containing $25 \%$ clay and $10 \%$ organic matter). All elements follow more or less the same pattern (especially in 1970).

Average values for the relative deviations from the mean for all six elements (compare Fig. 5) were averaged. This gave a general value for the relative deviation from the mean for heavy metal contamination levels for all locations studied. Results are 
1970

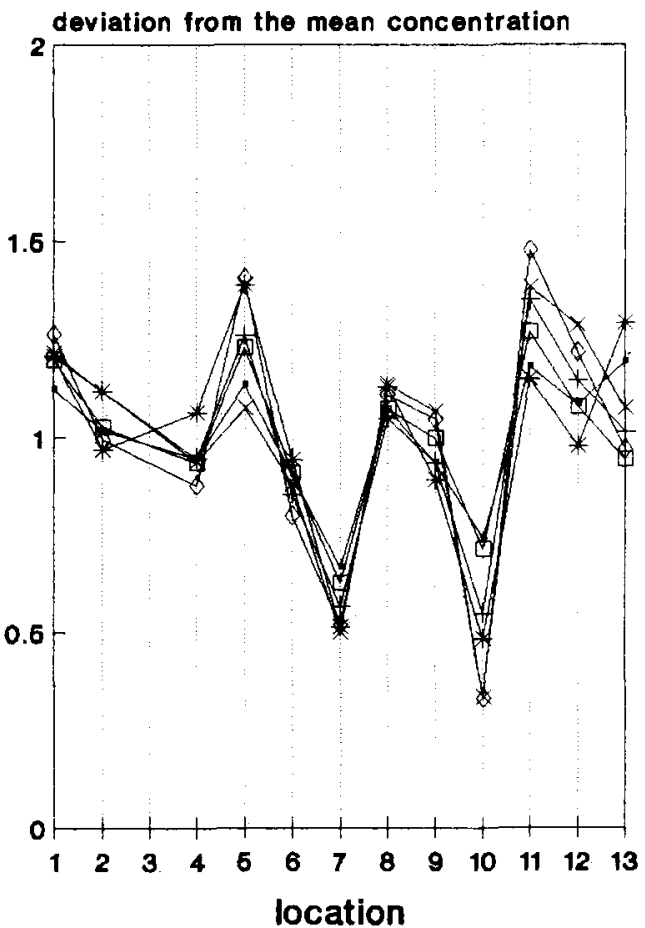

1981

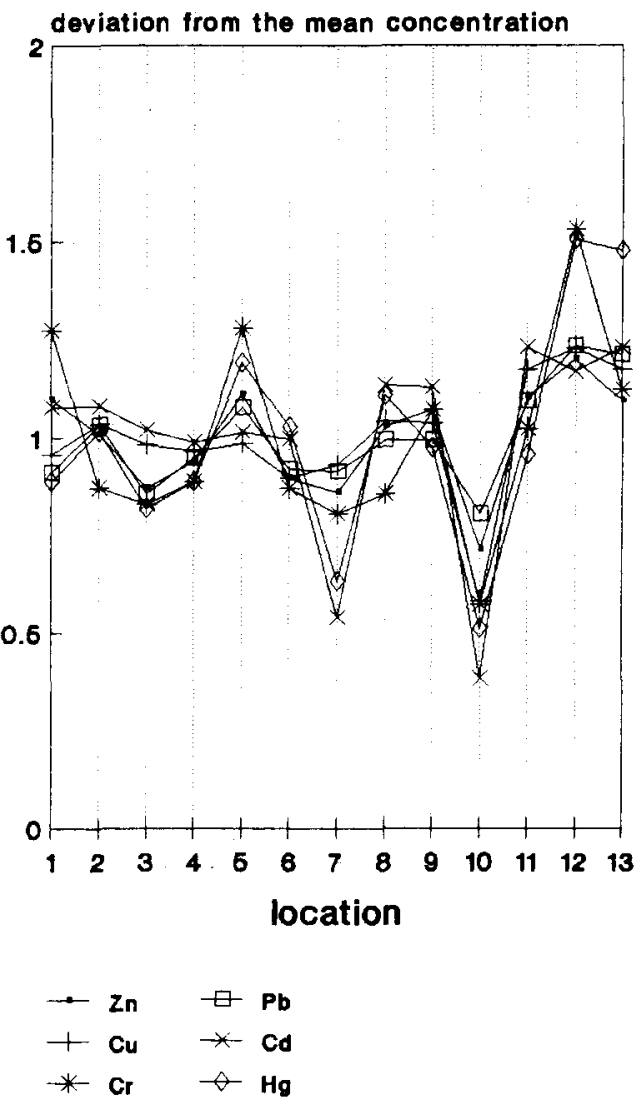

Fig. 5. Heavy metal contamination of floodplains in 1970 and 1981; variation between the locations given as relative deviations from the annual mean for individual elements.

presented in Figure 6. The locations were subdivided into two main classes: floodplains with a summer dyke and floodplains without a summer dyke. Floodplain 9 occupies an intermediate position having only a low levee instead of a summer dyke.

The results show that higher heavy metal levels in floodplains are found when a summer dyke is absent. These areas are already flooded at a moderate rise in water level; floodplains protected by summer dykes are flooded only at extremely high river discharges. This trend can be further supported by concentrations found in river sediment sampled at the Biesbosch/Nieuwe Merwede sedimentation area in 1970; here, suspended matter was deposited under average river discharge conditions and substantially higher concentration levels are found. Results for zinc and cadmium are given below (normalized to $50 \%$ particles $<16 \mu \mathrm{m}$ ) for the three types 
1970

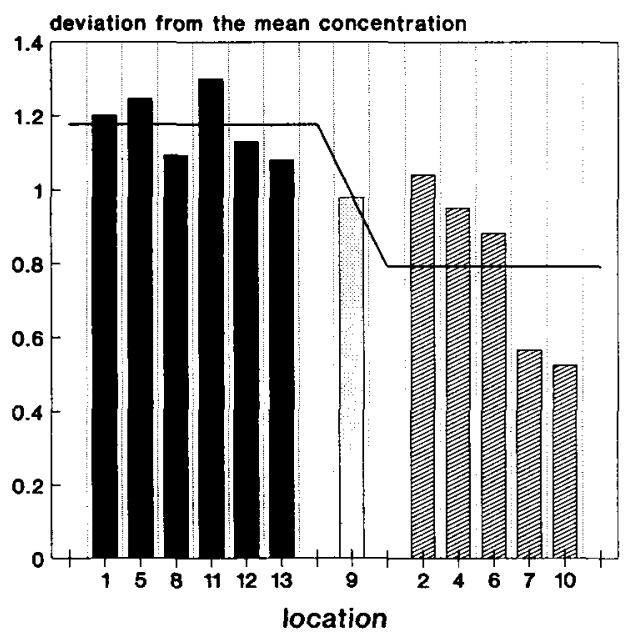

summer dyke

no summer dyke

low levee

- mean values
1981

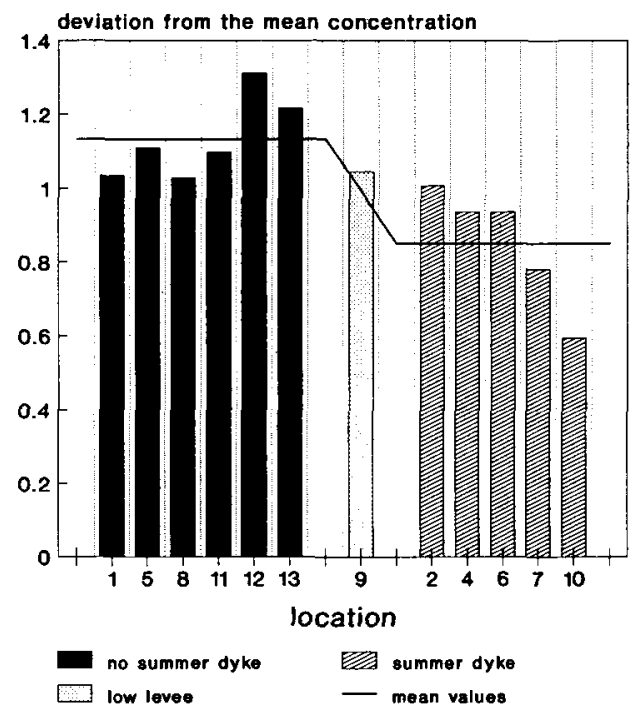

Fig. 6. Floodplain heavy metal contamination in 1970 and 1981; variation between the locations given as average relative deviations from the annual mean for all elements. The effect of summer dykes is shown.

of sediments:

- Rhine sediment (1970) (average annual water discharge):

$\mathrm{Zn}: 1855 \mathrm{mg} \mathrm{kg}^{-1}, \mathrm{Cd}: 27.1 \mathrm{mg} \mathrm{kg}^{-1}$

- Floodplain sediment (1970) (without summer dykes) (moderately high water discharge):

$\mathrm{Zn}: 943 \mathrm{mg} \mathrm{kg}^{-1}, \mathrm{Cd}: 12.3 \mathrm{mg} \mathrm{kg}^{-1}$

- Floodplain sediment (1970) (with summer dykes) (very high water discharge):

$\mathrm{Zn}: 690 \mathrm{mg} \mathrm{kg}{ }^{-1}, \mathrm{Cd}: 7.9 \mathrm{mg} \mathrm{kg-1}$

A clear relationship exists between water discharge and contaminant levels in the sediments: the higher the discharge the lower the heavy metal concentration levels. For suspended matter in the river Rhine this relationship was described by Salomons \& Eysink (1981) (Fig. 7).

It can be concluded that the differences between floodplains protected by summer dykes and floodplains without a summer dyke shown in Figure 6 are accounted for by differences in river discharge.

\section{Classification of pollution levels}

Different methods are used for the classification of soils with respect to heavy metal contamination. Some are used as a tool to decide whether or not a soil should be 
$\mathrm{Zn}$

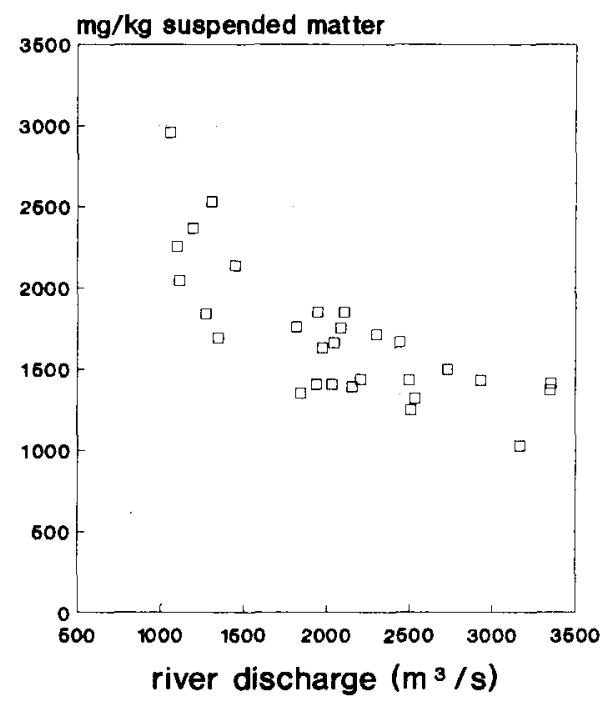

Cd

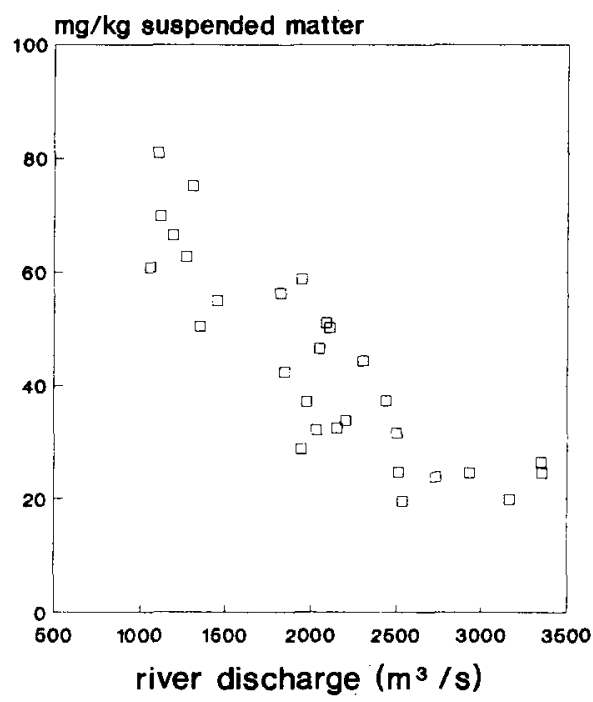

Fig. 7. Relationship between water discharge and $\mathrm{Zn}$ and $\mathrm{Cd}$ concentrations in suspended matter of the river Rhine (1977/78).

removed and cleaned. Other methods are used as an instrument for land use classification. Still other methods exist which classify the degree of pollution in relation to natural background levels.

A short outline of three different approaches is given below.

Comparison with natural background levels - Igeo-values

The experimentally found concentrations can be related to naturally occurring background levels of the heavy metals in order to determine the relative degree of contamination for each element. A straightforward classification into readily recognizable indexed groups indicating pollution severity proved to be useful. In Germany, Müller (1978) introduced a quantitative measure of the metal pollution in aquatic sediments, which is called the 'index of geoaccumulation':

$$
\text { Igeo }={ }^{2} \log (C / 1.5 \times B)
$$

where:

$C=$ the measured concentration of the element in question

$B=$ the estimated background level of the element in question

Both $B$ and $C$ are values normalized to $50 \%$ particles $<16 \mu \mathrm{m}$, because the values for background levels were expressed as such. Müller originally introduced the method for the fraction of particle size $<2 \mu \mathrm{m}$; the different normalization methods, however, do not give substantial differences for our data set. 
The factor 1.5 in the formula is used to account for possible variations in the background levels due to lithogenic effects.

$B$ is determined through the analysis of sediments deposited in the past, when little or no heavy metal contamination through human activities existed. The data sets used here are based on measurements by Salomons (1989) in sediments sampled in 1922. Other data sets give comparable background values.

Based on Igeo-values, the degree of pollution can now be classified as follows:

\begin{tabular}{|c|c|c|}
\hline Igeo & Igeo pollution class & Description \\
\hline$>5$ & 6 & very strongly polluted \\
\hline $4-5$ & 5 & strongly to very strongly polluted \\
\hline $3-4$ & 4 & strongly polluted \\
\hline $2-3$ & 3 & moderately to strongly polluted \\
\hline $1-2$ & 2 & moderately polluted \\
\hline $0-1$ & 1 & unpolluted to moderately polluted \\
\hline$<0$ & 0 & practically unpolluted \\
\hline
\end{tabular}

Igeo-values were calculated using the following background values: $\mathrm{Zn} 68 \mathrm{mg}$ $\mathrm{kg}^{-1}, \mathrm{Cu} 13 \mathrm{mg} \mathrm{kg}^{-1}, \mathrm{Cr} 72 \mathrm{mg} \mathrm{kg}^{-1}, \mathrm{~Pb} 21 \mathrm{mg} \mathrm{kg}^{-1}, \mathrm{Cd} 0.25 \mathrm{mg} \mathrm{kg}^{-1}$, Ni $29 \mathrm{mg}$ $\mathrm{kg}^{-1}, \mathrm{Hg} 0.1 \mathrm{mg} \mathrm{kg}^{-1}$, As $15 \mathrm{mg} \mathrm{kg}^{-1}$.

Pollution degrees based on Igeo-values are shown in Figure 8.

It can be concluded that most of the nickel present in the floodplain sediments is of natural origin. For arsenic the pollution level has decreased rapidly and the more recent floodplain sediments are practically uncontaminated with this element. Even in 1981, sediments continued to be heavily to very heavily polluted with cadmium.

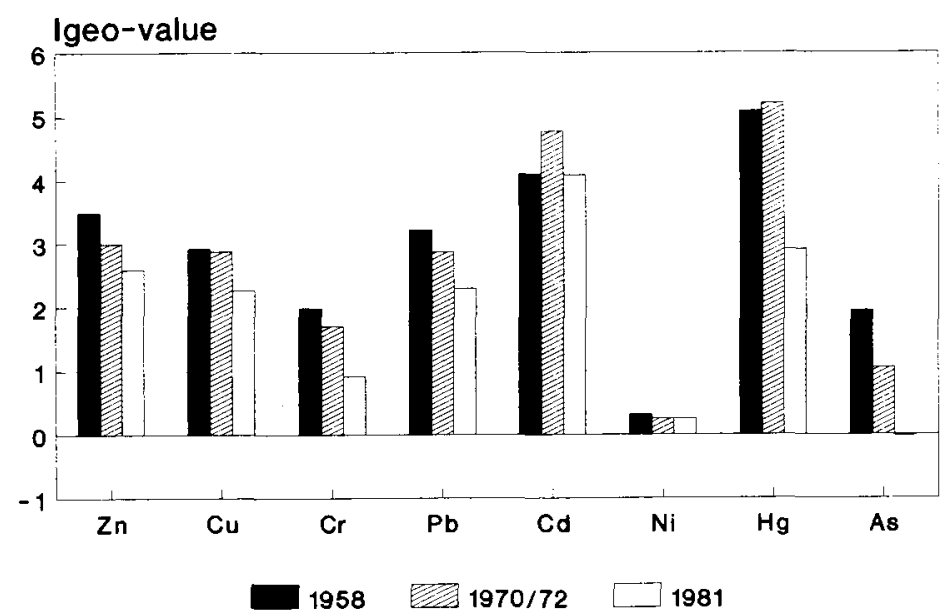

Fig. 8. Heavy metal pollution in freshly deposited sediments from the river Waal floodplains in different years, compared with natural background levels (Igeo-values). 
Comparison with reference values

Pollution levels can also be estimated on the basis of reference values given in Table 5 (Anonymous, 1987, 1988). These values are upper limits for soils, considered to be multifunctional soils by the Dutch authorities; it means that at these heavy metal concentrations no harmful effects on organisms have been found (de Groot; pers. comm.). Reference values are used as a basis for possible source-oriented environmental protection measures to be taken by the authorities.

Figure 9a gives the proportion between the experimentally found average values (1970 and 1972 taken together to improve visualization) and the reference values from Table 5 . Figure $9 \mathrm{~b}$ shows the same values but now compared with so-called

Table 5. Heavy metal reference values $R$ and signal values $S$ for standard soil containing $25 \%$ clay and $10 \%$ organic matter $\left(\mathrm{mg} \mathrm{kg}^{-1}\right.$ dry matter).

\begin{tabular}{lll}
\hline $\mathrm{Zn}$ & $\mathrm{R}(\mathrm{Zn})=140$ & $\mathrm{~S}(\mathrm{Zn})=2500$ \\
$\mathrm{Cu}$ & $\mathrm{R}(\mathrm{Cu})=36$ & $\mathrm{~S}(\mathrm{Cu})=400$ \\
$\mathrm{Cr}$ & $\mathrm{R}(\mathrm{Cr})=100$ & $\mathrm{~S}(\mathrm{Cr})=600$ \\
$\mathrm{~Pb}$ & $\mathrm{R}(\mathrm{Pb})=85$ & $\mathrm{~S}(\mathrm{~Pb})=700$ \\
$\mathrm{Cd}$ & $\mathrm{R}(\mathrm{Cd})=0.8$ & $\mathrm{~S}(\mathrm{Cd})=30$ \\
$\mathrm{Ni}$ & $\mathrm{R}(\mathrm{Ni})=35$ & $\mathrm{~S}(\mathrm{Ni})=100$ \\
$\mathrm{Hg}$ & $\mathrm{R}(\mathrm{Hg})=0.3$ & $\mathrm{~S}(\mathrm{Hg})=15$ \\
$\mathrm{As}$ & $\mathrm{R}(\mathrm{As})=29$ & $\mathrm{~S}(\mathrm{As})=100$ \\
\hline
\end{tabular}
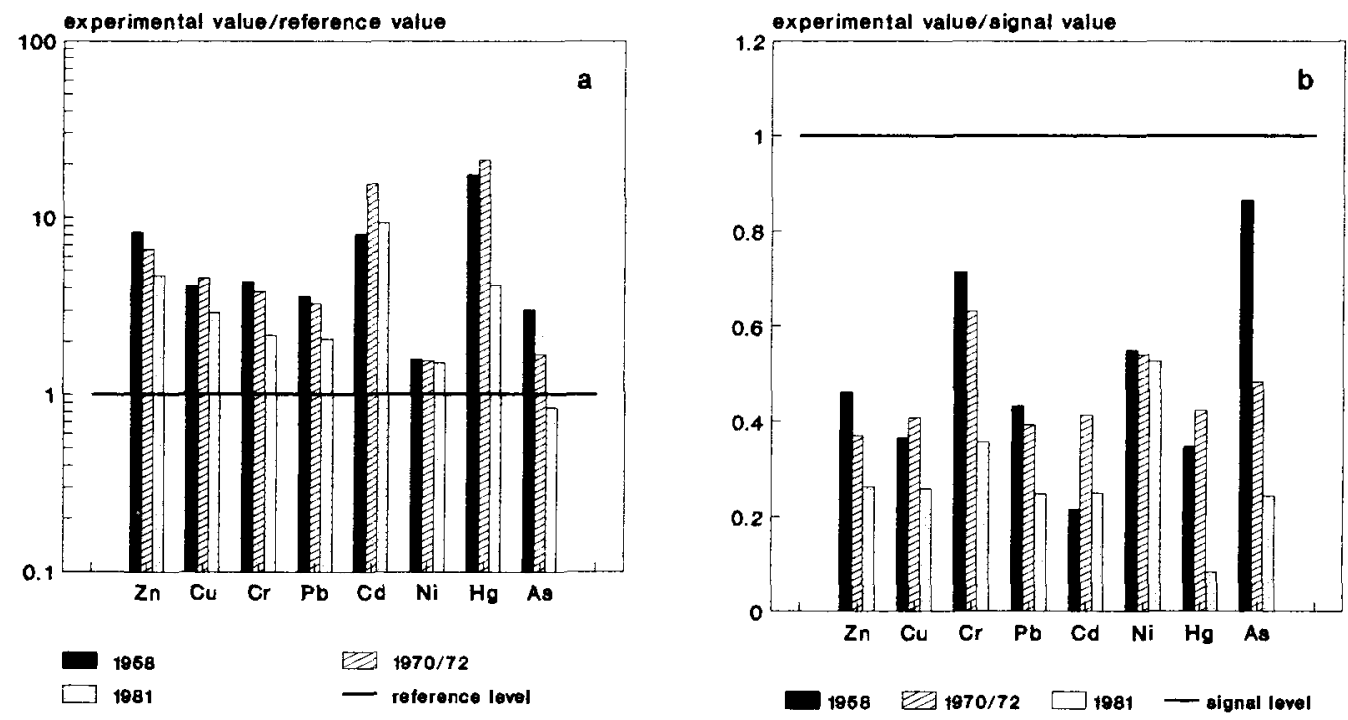

Fig. 9. Heavy metal pollution in freshly deposited sediments from the river Waal floodplains in different years, compared with reference values (a) and signal values (b). 
'signal values', also given in Table 5. These values are regarded as alarm levels for sediments by the Dutch authorities (Anonymous, 1988); at such levels removal and clean-up of the soil is considered.

The figures show that the heavy metal levels generally exceed the reference values by a factor of 5 to 10; only the nickel and arsenic levels are close to the reference values. Signal values were never exceeded.

For organic micropollutants the reference values used (normalized to standard soil containing $10 \%$ organic matter) (Anonymous, 1988) are given in Table 6. In the case of PCB's, reasonable doubt exists with respect to the given value (de Groot, pers. comm.). Figure 10a gives the ratio between the experimentally found average values (1970 and 1972 taken together) and the reference values from Table 6. Figure $10 \mathrm{~b}$ shows the same values but now compared with so-called 'signal values'.

PCB, HCB and DDT levels exceeded the reference values by a factor of up to 100 . Signal values were reached for PCB in many samples.

Table 6. Organic micropollutant reference values $\mathrm{R}$ and signal values $\mathrm{S}$ for standard soil containing $10 \%$ organic matter ( $\mathrm{mg} \mathrm{kg}^{-1}$ dry matter).

\begin{tabular}{lll}
\hline PAH & R(PAH) $=2.3$ & $\mathrm{~S}(\mathrm{PAH})=17$ \\
PCB & $\mathrm{R}(\mathrm{PCB})=0.02$ & $\mathrm{~S}(\mathrm{PCB})=0.4$ \\
DDT & $\mathrm{R}(\mathrm{DDT})=0.0025$ & $\mathrm{~S}(\mathrm{DDT})=0.5$ \\
$\mathrm{HCB}$ & $\mathrm{R}(\mathrm{HCB})=0.0025$ & $\mathrm{~S}(\mathrm{HCB})=0.5$ \\
\hline
\end{tabular}
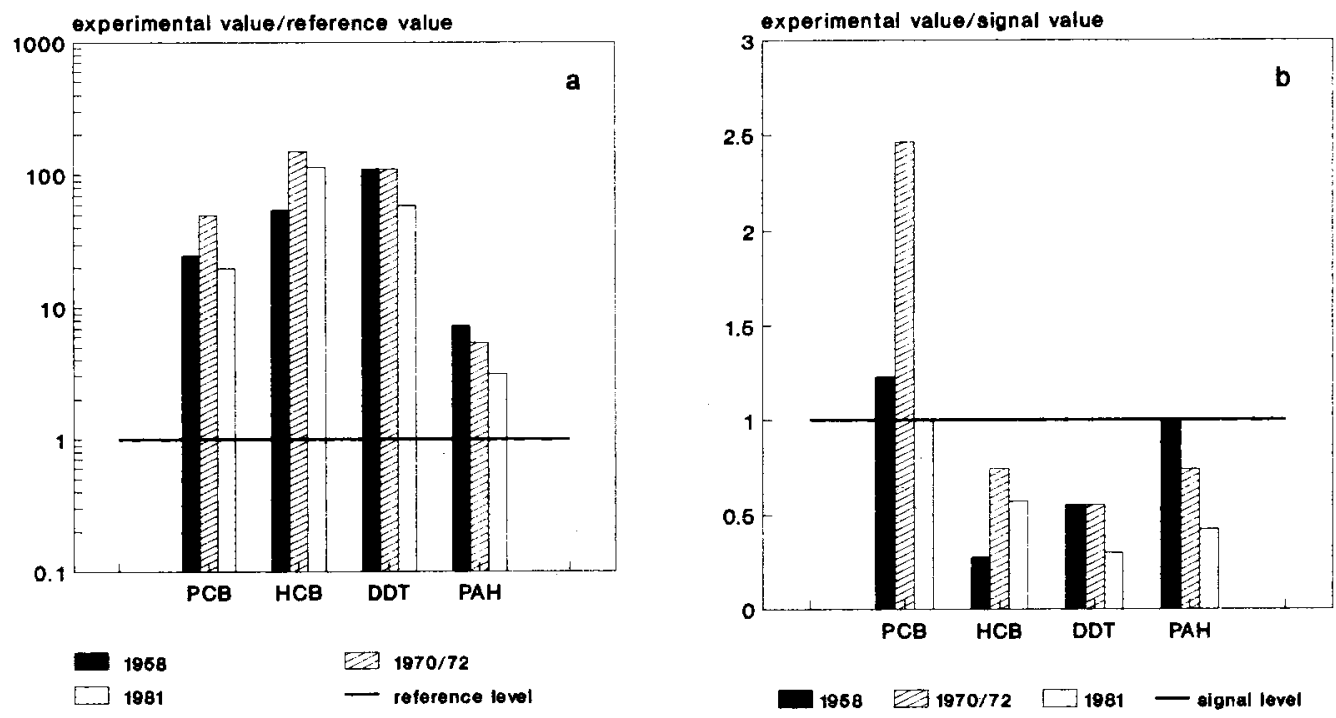

Fig. 10. Organic micropollutant pollution in freshly deposited sediments from the river Waal floodplains in different years, compared with reference values (a) and signal values (b). 


\section{$L A C$ values}

The Dutch Ministry of Agriculture developed a set of values for contaminant levels in agricultural soils, the so-called LAC values (named after the technical committee which developed them) (Anonymous, 1986). These values are meant to indicate the levels above which problems might arise for plant and animal well-being or the quality of agricultural products. LAC values are dependent on soil type and land use: heavy metal availability is strongly dependent on soil composition (adsorption capacity) and on the uptake characteristics of the organisms. Because floodplain sediment deposits can be considered as clay soils used for grazing cattle and sheep, the following values are used:

- Zn: $350 \mathrm{mg} \mathrm{kg}^{-1}$ dry matter,

- Cu: $80 \mathrm{mg} \mathrm{kg}^{-1}$ dry matter (used for grazing cattle), $30 \mathrm{mg} \mathrm{kg}^{-1}$ dry matter (used for grazing sheep),

- Pb: $150 \mathrm{mg} \mathrm{kg-1}^{-1}$ dry matter,

- Cd: $3 \mathrm{mg} \mathrm{kg-1}^{-1}$ dry matter,

- Hg: $2 \mathrm{mg} \mathrm{kg}^{-1}$ dry matter.

The metal levels in most samples analysed were well above the LAC values. There is no evidence that cattle take in larger amounts of heavy metals when they graze in floodplains as compared with areas that are not polluted with river sediments. This might be due to the high contents of organic matter and carbonate in the floodplain sediments (van de Ven et al., 1977). Plant uptake of organic micropollutants is limited but cattle tend to consume considerable amounts of soil; milk from cattle grazing in the floodplain areas shows elevated but not alarming PCB levels (Roos et al., 1984). Eggs from birds of prey and owls living in the floodplains show increased organic micropollutant levels (Fuchs et al., 1981).

\section{Conclusion}

The environmental protection measures taken during the past decades in the countries bordering the Rhine have had a measurable effect on the quality of suspended matter as reflected in the pollution of freshly deposited sediments. This is valid both for heavy metals and organic micropollutants. However, due to their immobility and chemical persistence, the pollutants described here will remain in the upper layer of the floodplain soil for many years. A real improvement of floodplain soil quality can be expected only in the next decades (if the decrease in input continues).

\section{References}

Anonymous, 1986. 'Signal values' for contents of environmentally-critical substances in soil concerning the possibilities for agricultural use of contaminated soils. Rapport 86.1. Landbouw Advies Commissie Milieukritische stoffen (LAC), Ministry of Agriculture and Fisheries, The Hague, Netherlands. (In Dutch).

Anonymous, 1987. Environmental Programme 1988-1991: Progress Report. Ministry of Housing, Regional Development and the Environment/Ministry of Agriculture and Fisheries/Ministry of Transport and Construction. SDU, The Hague, Netherlands. (In Dutch). 
Anonymous, 1988. Environmental Programme 1989-1992: Progress Report. Ministry of Housing, Regional Development and the Environment/Ministry of Agriculture and Fisheries/Ministry of Transport and Construction. SDU, The Hague, Netherlands. (In Dutch).

Borneff, J. \& H. Kunte, 1969. Kanzerogene Substanzen in Wasser und Boden XXVI. Routinemethode zur Bestimmung von Polyzyklischen Aromaten im Wasser. Archiv für Hygiene und Bakteriologie 153: 220-229.

Fuchs, P. \& J. B. M. Thissen, 1981. Die Pestizid- und PCB-Belastung bei Greifvögel und Eulen in den Niederlande nach den gesetzlich verordneten Einschränkungen im Gebrauch der chlorierten Kohlenwasserstofpestiziden. In: H. Eilenberg (Ed.), Ökologie der Vögel, p. 181-195. Biebach, Stuttgart, FRG.

Groot, A. J. de, K. H. Zschuppe \& W. Salomons, 1982. Standardization of methods of analysis for heavy metals in sediments. In: P. G. Sly (Ed.), Sediment/freshwater interactions, p. 689-696. Junk, Dordrecht, Netherlands.

Japenga, J., W. J. Wagenaar, F. Smedes \& W. Salomons, 1987. A new, rapid clean-up procedure for the simultaneous determination of organic micropollutants in sediments; application in two European estuarine sediment studies. Environmental Technology Letters 8: 9-20.

Kilmer, V. J. \& L. T. Alexander, 1949. Methods of making mechanical analyses of soils. Soil Science 68: $15-24$.

Müller, G., 1978. Schwermetalle in den Sedimenten des Rheins. Veränderungen seit 1971. Umschau der Wissenschaft und Technologie 79: 778-783.

Roos, A. H. \& L. G. M. Th. Tuinstra, 1984. Survey of the chlorobiphenyl contents of compound feed and roughage in relation to the chlorobiphenyl contents in milk on the same farm. Rapport 84.3. State Institute for Quality Control of Agricultural Products, Wageningen, Netherlands. (In Dutch).

Salomons, W., 1989. Fate and behaviour of trace metals in a shallow eutrophic lake. In: A. Boudou \& F. Ribeyre (Eds), Aquatic ecotoxicology: fundamental concepts and methodologies, Vol. I, p. 185199. CRC Press, Boca Raton, Fl, USA.

Salomons, W. \& W. Eysink, 1981. Pathways of mud and particulate trace metals from rivers in the Southern North Sea. Special Publications International Association of Sedimentologists 5: 429-450.

Ven, W. S. M. van de, J. Gerbens, W. van Driel, J. J. M. de Goeij, P. S. Tjoe, C. Holzhauer \&

J. H. P. Verweij, 1977. Trace elements in cattle from areas along the Rhine and IJssel rivers. Landbouwkundig Tijdschrift 89: 262-269. (In Dutch).

Vierveijzer, H. C., A. Lepelaar \& J. Dijkstra, 1979. Analytical methods for soil, sewage sludge, crop and liquids. Instituut voor Bodemvruchtbaarheid, Haren, Netherlands. (In Dutch). 